26 Navani M, Robinson C. Clinical challenge with Implanon ${ }^{\circledR}$ removal: a case report. J Fam Plann Reprod Health Care 2005; 31: 161-162.

27 Ismail H, Mansour D, Singh M. Migration of Implanon ${ }^{\circledR}$. J Fam Plann Reprod Health Care 2006; 32: 157-159.

28 Cozens NJA. Contraceptive implants: high resolution ultrasonography facilitates removal. Br Med J 1996; 313: 880.

29 Evans R, Holman R, Lindsay E. Migration of Implanon ${ }^{\circledR}$ : two case reports. J Fam Plann Reprod Health Care 2005; 31: 71-72.

30 Westerway SC, Picker R, Christie J. Implanon implant detection with ultrasound and magnetic resonance imaging. Aust N Z J Obstet Gynaecol 2003; 43: 346-350.

31 Shulman LP, Gabriel H. Management and localization strategies for the nonpalpable Implanon rod. Contraception 2006; 73: 325-330.

32 Sarma SP, Silverstein M, Lewis C. Removal of a Norplant $\mathbb{R}$ implant located near a major nerve using interventional radiology-digital subtraction fluoroscopy. Contraception 1998; 58: 387-389.

33 Newton MP, Mascarenhas L, Xiao-Feng L, Newton J. Experience with contraceptive implants: removal technique, classification of difficulties and the importance of correct placement. Br J Fam Planning 1995; 21(Suppl.): 14-16.

34 Nelson AL, Sinow RM. Real-time ultrasonographically guided removal of nonpalpable and intramuscular Norplant capsules. Am J Obstet Gynecol 1998; 178: 1185-1193.

35 Mansour D. UK provision for removal of non-palpable contraceptive implants. J Fam Plann Reprod Health Care 2009; 35: 3-4.

36 Faculty of Sexual \& Reproductive Healthcare. For a woman using the etonogestrel implant, Implanon, which has been found to be located in her biceps muscle, should it be removed under local anaesthetic? Members' Enquiry 1766. 20 September 2006. Clinical Effectiveness Unit: on file.

37 James $P$, Trenery J. Ultrasound localisation and removal of non-palpable Implanon implants. Aust N Z J Obstet Gynaecol 2006; 46: 225-228.

38 Vidin E, Garbin O, Rodriguez B, Favre R, Bettahar-Lebugle K. Removal of etonogestrel contraceptive implants in the operating theater: report on 28 cases. Contraception 2007; 76: 35-39.

39 C v Sefton Primary Care Trust Lawtel LTLPI; 24 August 2005.

40 Mansour D, Walling M, Glenn D, Egarter C, Graesslin O, Herbst J, et al. Removal of non-palpable etonogestrel implants. J Fam Plann Reprod Health Care 2008; 34: 89-91.

41 Mourtialon P, Tixier H, Loffroy R, Maillart JC, Calmelet P,
Dellinger $\mathrm{P}$, et al. Vascular complication after insertion of a subcutaneous contraceptive implant. Acta Obstet Gynecol Scand 2008; 87: 1256-1258.

42 Searle ES. Norplant neuropathy [Letter]. Br J Fam Planning 1994; 20: 101

43 Chang A, Edlich RF, Himel HN. Local reactions at the insertion site of the Norplant contraceptive system. J Long Term Eff Med Implants 1993; 3: 305-312.

44 Sarma SP, Hatcher RA. Neurovascular injury during removal of levonorgestrel implants. Am J Obstet Gynecol 1995; 172: 120-121.

45 Arribas-Mir L, Rueda-Lozano D, Agrela-Cardona M, CedeñoBenavides T, Olvera-Porcel C, Bueno-Cavanillas A. Insertion and 3-year follow-up experience of 372 etonogestrel subderma contraceptive implants by family physicians in Granada, Spain. Contraception 2009; 80: 457-462.

46 Nash C, Staunton T. Focal brachial cutaneous neuropathy associated with Norplant ${ }^{\circledR}$ use: suggests careful consideration of the recommended site for inserting contraceptive implants. J Fam Plann Reprod Health Care 2001; 27: 155-156.

47 Wechselberger G, Wolfram D, Pülzl P, Soelder E, Schoeller T. Nerve injury caused by removal of an implantable hormonal contraceptive. Am J Obstet Gynecol 2006; 195: 323-326.

48 Webb AMC. Why go to Tiger Country? A report of two cases of Implanon ${ }^{\circledR}$ removal. J Fam Plann Reprod Health Care 2006; 32: 193-194.

49 Marin R, McMillian D. Ulnar neuropathy associated with subdermal contraceptive implant. South Med J 1998; 91: 875-878.

50 Smith JM, Conwit RA, Blumenthal PD. Ulnar nerve injury associated with removal of Norplant implants. Contraception 1998; 57: 99-101.

51 Osman N, Mirlesse V. A new complication of contraceptive hormonal implant: about two cases of lesions of the ulnar nerve at the arm level [in French]. Gynecol Obstet Fertil 2005; 33: 322-325.

52 Bragg TWH, Jose RM, Bland JW, Matthews RN, Srivastava S. Implantable contraceptive devices: primum non nocere. J Fam Plann Reprod Health Care 2006; 32: 190-192.

53 Anonymous. Nerve damage blamed on contraceptive implant placement. Clinician Reviews 2007; 17: 15.

54 Medicines and Healthcare products Regulatory Agency (MHRA). Download Drug Analysis Prints (DAPs). http://www.mhra.gov.uk/Onlineservices/Medicines/Druganaly sisprints/index.htm [Accessed 22 July 2010].

55 Berner LS. Implants, Norplant: dejà vu all over again. $\checkmark$ Womens Health 1995; 4: 353-355.

\title{
NEWS ROUNDUP
}

\section{'My Contraception Tool' launched} Sexual health charities Brook and FPA have launched 'My Contraception Tool' (v. 1.0) a web tool designed to support people's contraceptive choices by evaluating their preferences and priorities as well as their physical needs. This new web tool allows patients to search for options in contraception tailored to their needs. The circumstances, medical history and personal preferences are input by the user online. These data are then processed and each contraceptive method is ranked in order to suit individual needs. The results can then be printed and taken to help initiate conversations with a health care professional

The tool is designed for use by men and women of any age who want to use contraception and is linked to further information about each contraceptive method as well as a wealth of information on other aspects of sexual health.

Sources: www.brook.org.uk/mycontraceptiontool and

www.fpa. org.uk/mycontraceptiontool

\section{Study confirms HPV vaccine more} effective than previously thought

Scientists at the Health Protection Agency (HPA), the University of Manchester and the Manchester Royal Infirmary have found that the cervical cancer vaccine could prevent more cases of the disease in England than previously thought, according to a study published in the British Journal of Cancer. This could potentially reduce the annual number of cases from around 3000 to less than 700 .

Cervical cancer is caused by an infection called human papillomavirus (HPV). The study found that $73-77 \%$ of cervical cancer cases were caused by either HPV type 16 or 18 , both of which are prevented by the current vaccine used in the UK. Prior to this study, the available data had suggested $70 \%$ of cases were caused by these types. Current vaccines do not protect against all HPV types that cause cervical cancer, but they do protect against these two most common types.

\section{Reference}

Howell-Jones R, Bailey A, Beddows S, Sargent A, de Silva N, Wilson G, et al.; Study Group Collaborators. Multi-site study of HPV type-specific prevalence in women with cervical cancer, intraepithelial neoplasia and normal cytology, in England. Br J Cancer 2010; 103: $209-216$.

\section{'The Middle-age Spread' \\ (STIs in the over-50s)}

Growth in sexually transmitted infections (STIs) amongst the over-50s has reached alarming proportions. A recent poll by the Royal Pharmaceutical Society of Great Britain found that almost one in five of 45-54-year-olds admitted to having unprotected sex with someone other than a long-term partner. And a further $20 \%$ believed that their chances of picking up an STI were "next to nothing" in these circumstances. A campaign to remind the over-50s that they are at risk from STIs has been launched by sexual health charity, FPA. Entitled 'The Middle-age Spread', the campaign has a message for men and women in that age group who are starting new relationships: "You may not think it applies to you, but if you are having sex with a new partner, you can catch an STI as easily as someone in their 20s".

Source: http://www.fpa.org.uk/Campaignsandadvocacy/Sexual HealthWeek/stisandsafersexover 50

\section{New interactive text messaging} service for young people

Ask Brook has added a text service to its helpline and online service. Young people can text Ask Brook with any question about sexual health or relationships and receive an individual response within one working day. The text number is 07717989023 and all text messages are confidential. Texts will be charged at the young person's standard network rate. Ask Brook Helpline on 08088021234 is available from 9.00am until 7.00pm Monday to Friday.

Source: www.askbrook.org.uk

Reviewed by Henrietta Hughes, MRCGP, DFSRH General Practitioner, London, UK 